\title{
MEMAHAMI JIHAD DALAM PERSPEKTIF ISLAM (UPAYA MENANGKAL TUDUHAN TERORISME DALAM ISLAM)
}

\author{
Amri Rahman \\ Universitas Negeri Makasar \\ abu.aimanwajwad@gmail.com
}

\begin{abstract}
This research is aimed at understanding the Islamic perspective of jihad derived from The Holy Quran and hadits of The Prophet Muhammad peace be upon to him. It is a library research that is classified as expanded qualitative-descriptive research. The research found that Jihad term in the Holy Quran that means "hard work "found in 33 verses. These verses have a broad meaning namely a totally hard work in all aspect of life. Despite it is undeniable that there is a verse using Jihad term that means a physical fighting or hold weapon to combat the enemy. But many other verses using Jihad term that means a hard work in universal meaning. Jihad in the Holy Quran has three meanings, namely: (1) carrying on a battle or combat an enemy,(2) fighting for conquering the devil (syaitan), and (3) trying hard to conquer our ego. Islamic religion teaches to maintain a peaceful life and prohibit all kind of destruction. So, term of terrorism is not found in Islamic teaching. Jihad is not synonym to terrorism because jihad is not an anarchy action but fully devoted to gain the bounty of Allah.
\end{abstract}

Keywords: jihad, Islamic perspektif, rahmatan lil alamin

\begin{abstract}
Abstrak: Penelitian ini bertujuan untuk mengetahui pandangan Islam tentang jihad yang bersumber dari al-Qur'an dan hadis Rasulullah Saw. Penelitian yang dilakukan adalah penelitian kepustakaan (library research) yang tergolong kualitatif deskriptif yang bersifat pengembangan. Hasil penelitian menunjukkan bahwa term jihad dalam al-Qur'an yang mengandung pengertian "berjuang" ditemukan sejumlah 33 ayat. Ayat-ayat tersebut mengandung pengertian yang luas, yakni perjuangan secara total yang meliputi seluruh aspek kehidupan, sekalipun tidak dapat dipungkiri adanya ayat yang mengandung pengertian bahwa jihad yang dimaksud adalah perang fisik atau mengangkat senjata terhadap para pembangkang atau terhadap musuh. Tetapi ayat-ayat yang lain justru jihad dimaknai dengan perjuangan yang bersifat universal. jihad dalam al-Qur'an mempunyai tiga arti, yaitu: (1) berjuang melawan musuh nyata, (2) berjuang melawan (memusuhi) syetan, dan (3) berjuang melawan hawa nafsu. Islam adalah agama yang mengajarkan kedamian dan melarang keras segala bentuk kekerasan, dengan demikian term terorisme tidak dikenal dalam ajaran Islam. Jihad dan terorisme tidak dapat disandingkan karena jihad bukan tindakan anarkis melainkan usaha sungguh-sungguh untuk meraih ridha Allah Swt.
\end{abstract}

Kata-kata kunci: jihad, perspektif Islam, rahmatan lil alamin 


\section{PENDAHULUAN}

Aksi kekerasan sering terjadi antara individu dengan individu, suku dengan suku, kelompok agama dengan agama lain, bahkan antar golongan dalam satu komunitas beragama, hampir muncul silih berganti. Dan tidak sedikit dari semua itu, menimbulkan korban jiwa, materiil, dan perasaan mencekam, akhirnya, rasa aman menjadi barang mewah.

Tragedi bom Bali dan penyerangan dua gedung pencakar langit World Trade Center (WTC) di Amerika menghetakkan mata dunia bahwa kekerasan masih dianggap suatu cara untuk menyelasaikan masalah. Terorisme yang dilakukan kelompok-kelompok tertentu dengan cara menebarkan ketakutan dimana-mana sekarang hampir menjadi trend kejahatan internasional. Dalam ungkapan Rumadi sebgaimana dikutip Afifuddin $(2017$; 95) bahwa ketika terorisme telah berkembang sedemikian rupa, maka rasa aman menjadi sesuatu yang sangat mahal.

Fenomena terorisme yang mengatasnamakan Islam dengan cara bom bunuh diri sangat meresahkan masyarakat. Banyak pihak mengecam dan menyalahkan Islam atas kejadian tersebut karena aksi itu sebagai sebuah perjuangan membela agama atau dengan kata lain "jihad" oleh pelakunya. Jihad adalah konsep perjuangan membela agama dalam Islam. Hal inilah menjadi awal mula terorisme dididentikkan dengan Islam. Padahal model jihad yang dipraktikkan teroris dengan jalan bom bunuh diri dan pembunuhan orang tak berdosa berbeda jauh dari konsep jihad yang sebenarnya sesuai dengan al-Qur'an.

Kehadiran al-Qur'an dengan seluruh petunjuk, keteranganketerangan, aturan-aturan, prinsip-prinsip, dan konsep-konsep, baik secara global maupun terperinci, eksplisit maupun implisit, yang bertujuan untuk merealisasikan agar tatanan hidup manusia dapat lebih baik, seharusnya dapat betul-betul menjadi way of life yaitu pedoman hidup bagi umat manusia sehingga dapat merasakan kehidupan yang aman, tentram, damai, dan sejahtera.

Al-Qur'an telah menegaskan, bahwa ia turun untuk menjadi hudan/petunjuk -ke jalan yang benar menuju kemaslahatan hidup di dunia dan akhirat- kepada manusia secara keseluruhan, walaupun yang memfungsikannya dengan baik sebagai hudan hanya orang-orang yang bertakwa. Selain itu, ia juga berfungsi sebagai furqān (pembeda), yakni ia menjadi tolok ukur dan pembeda antara kebenaran dan kebatilan, termasuk dalam penerimaan dan penolakan (receive and 
denial) apa yang dinisbahkan kepada Nabi Muhammad saw. Sejalan dengan fungsi tersebut, Al-Qur'an mengajarkan sejumlah nilai, norma, sifat, dan tindakan (action) yang bersifat universal, yang dapat mengantar manusia untuk mencapai kualitas hidup mereka yang bermartabat lagi mulia (Mardan, 2009:2).

Universalitas Al-Qur'an terletak pada kandungannya yang tidak terbatas hanya pada persoalan keagamaan yaitu menyangkut pola hubungan antara hamba dengan Sang Khalik, namun ia meliputi hal-hal yang berkaitan dengan pola hubungan sesama makhluk-Nya, baik itu manusia, hewan, dan tumbuh-tumbuhan. Terhadap sesama makhluk Allah, bukan hanya kepada kelompok manusia yang memiliki keyakinan yang sama tetapi juga yang berbeda keyakinan sekalipun.

Bahkan tuntunan Al-Qur'an bukan hanya untuk kalangan muslim, tetapi juga manusia di seantero dunia. Muhammad sebagai Rasulullah yang dipercayakan untuk menyampaikan isi dan kandungan Al-Qur'an juga diutus untuk menjadi rahmatan lilalamin atau menjadi rahmat bagi seluruh semesta alam. Maka Islam yang didakwakan oleh Rasulullah saw. juga merupakan agama rahmat yang dapat menyinari dan memberikan perlindungan bagi siapa pun baik yang memeluknya maupun yang menolaknya sekalipun.

Jihad dan terorisme saat ini masih menjadi perbincangan panjang. Sebarapa dekatkah jarak antara jihad dan jahat?, dan mengapa kata jihad begitu menyeramkan bagi sebagian orang tidak luput oleh kaum muslimin sendiri?, mestikah jihad dianggap sebagai teror dari sebuah agama? Benarkah jihad bisa dilakukan oleh siapapun, kapanpun, dimanapun dan terhadap siapapun, sedangkan dalam alQur'an, jihad disandingkan dengan kata " $F i$ sabilillah" sehingga timbul pertanyaan, seperti apa jihad sebenarnya yang sesuai dengan jalan Allah tersebut.

Masalah-masalah tersebut merupakan perdebatan yang akan membutuhkan waktu yang panjang. Berdiam diri dan hanya mengkritik atau mencela suatu golongan tertentu merupakan suatu tindakan yang kurang bijak. Oleh karena itu dibutuhkan penjelasan untuk menjawab berbagai spekulasi dengan mengungkap pandangan al-Qur'an dan hadis mengenai jihad.

Seperti yang banyak terlihat dan terdengar, konsep Jihad dalam Islam dipandang dan diasumsikan secara negatif akibat ulah orangorang yang tidak bertanggung jawab sehingga melukai keindahan Islam itu sendiri. Konsep Jihad pun sering diputarbalikkan dan konotasi negatif pun tidak dapat dihindari; dan dari sudut mana pun 
Islam itu adalah sebuah ajaran yang mengutamakan kedamaian. Dan Jihad adalah kata bahasa Arab yang dalam penerjemahannya diartikan sebagai 'berjuang', tapi yang dipahami sekarang ini Jihad adalah 'bom bunuh diri'.

Perancuan makna jihad merupakan salah satu dampak dari berbagai aksi-aksi terosisme yang banyak terjadi. Islam selalu menjadi sasaran kesalahan akibat aksi kekeasan tersebut karena pelaku teror tersebut menyatakan apa yang mereka lakukan adalah jihad. Pengertian jihad yang masih banyak dipahami secara parsial oleh sebahagian umat Islam, maka dibutuhkan kajian yang mendalam untuk menemukan defenisi jihad menurut Al-Qur'an dan hadis-hadis Rasulullah Saw.

\section{Pembahasan}

\section{Terminologi Jihad dalam Al-Qur'an}

Muhammad Fuad (1992) mengatakan bahwa term jihad dengan berbagai derivasinya disebutkan dalam al-Qur'an sebanyak 41 kali, dari 41 term tersebut kebanyakan dengan bergandengan dengan term fisabilillah (di jalan Allah). Kata jihad yang mengandung pengertian "berjuang" ditemukan sejumlah 33 ayat. Ayat-ayat tersebut memberikan indikasi bahwa jihad mengandung pengertian yang luas, yakni perjuangan secara total yang meliputi seluruh aspek kehidupan, sekalipun tidak dapat dipungkiri adanya ayat yang mengandung pengertian bahwa jihad yang dimaksud adalah perang fisik atau mengangkat senjata terhadap para pembangkang atau terhadap musuh. Tetapi ayat-ayat yang lain justru jihad dimaknai dengan perjuangan yang bersifat universal.

Sebgaimana keberadaan ayat-ayat al-Qur'an yang terbagi ke dalam dua kategori yaitu ayat-ayat makkiyyah dan madaniyyah, ayatayat jihad juga ternyata ada yang makkiyah dan ada juga madaniyyah. Ayat-ayat jihad yang kategori makkiyah lebih tepat dimaknai dengan arti "bersungguh-sungguh" sebagaimana pengertiannya menurut bahasa. Maha jihad yang dimaksud disini adalah mengerahkan segenap kemampuan guna mencapai ridha Allah Swt. adapun ayat makkiyah yang memerintahkan untuk berjihad terhadap orang-orang kafir tidak dapat juga diartikan berperang melawan orang kafir karena tidak ada bukti secara historis tentang peperangan yang dilakukan oleh Rasulullah selama periode Mekah.

Keterangan di atas membuktikan bahwa jihad di dalam al-Qur'an pada umumnya berarti bersungguh-sungguh. Dengan demikian, dapat 
dipahami bahwa pemahaman tentang jihad yang selalu mengidentikkan dengan perang bukanlah sesungguhnya pemahaman yang bersifat qur'aniy (tidak bersumber dari al-Qur'an), bahkan sebuah kekeliruan kalau dikatakan bahwa semangat perang lahir dari ayatayat jihad dalam al-Qur'an.

Adapun kata atau istilah lain dalam al-Qur'an yang langsung mengandung arti perang adalah kata qital dan harb. Perang yang dimaksud adalah perang karena latar belakang pribadi atau kaum dengan bertujuan mencari keuntungan, bukan atas dasar meninggikan agama Allah Swt.

Terminologi jihad yang telah dikemukakan di atas melahirkan berbagai defenisi di kalangan ulama dan intelektual diantaranya; Menurut Ahmad Thayyeb (2016) jihad dapat dimaknai sebagai usaha keras dalam menaati Allah, dengan melaksanakan perintah-Nya dan menjauhi larangan-Nya. Termasuk juga usahanya dalam mengajak orang lain - muslim atau kafir - untuk menaati Allah, usahanya dalam memerangi orang kafir untuk meninggikan kalimat Allah, dan sebagainya. Sebuah upaya dikatakan sebagai jihad jika memenuhi syarat, yaitu dilakukan 'di jalan Allah'. Oleh karena itu, segala upaya yang dilakukan tidak di jalan Allah Ta'ala, maka tidak bisa dikatakan sebagai jihad.

Jihad (جهاد) adalah berjuang dengan sungguh-sungguh menurut syariat Islam. Jihad dilaksanakan untuk menjalankan misi utama manusia yaitu menegakkan agama Allah atau menjaga agama tetap tegak, dengan cara-cara yang sesuai dengan garis perjuangan para Rasul dan Al-Quran. Jihad yang dilaksanakan Rasul adalah berdakwah agar manusia meninggalkan kemusyrikan dan kembali kepada aturan Allah, menyucikan qalbu, memberikan pengajaran kepada ummat dan mendidik manusia agar sesuai dengan tujuan penciptaan mereka yaitu menjadi khalifah Allah di bumi.

Arti kata Jihad sering disalahpahami oleh orang yang tidak mengenal prinsip-prinsip agama Islam sebagai 'perang suci' (holy war); istilah untuk perang adalah Qital, bukan Jihad. Jihad dalam bentuk perang dilaksanakan jika terjadi fitnah yang membahayakan eksistensi ummat (antara lain berupa serangan-serangan dari luar).

Pada dasarnya arti kata jihad adalah "berjuang" atau "ber-usaha dengan keras", namun bukan harus berarti "perang dalam makna "fisik". Jika sekarang jihad lebih sering diartikan sebagai "perjuangan untuk agama", itu tidak harus berarti perjuangan fisik. Jika mengartikan jihad hanya sebagai peperangan fisik dan extern, untuk 
membela agama, akan sangat ber-bahaya, sebab akan mudah dimanfaat-kan dan rentan terhadap fitnah.

Quraish Shihab (1996:494) mengatakan bahwa jihad juga mengandung arti "kemampuan" yang menuntut sang mujahid mengeluarkan segala daya dan kemampuannya demi mencapai tujuan. Karena itu jihad adalah pengorbanan, dan dengan demikian sang mujahid tidak menuntut atau mengambil tetapi memberi semua yang dimilikinya. Ketika memberi, dia tidak berhenti sebelum tujuannya tercapai atau yang dimilikinya habis.

Berdasarkan keterangan-keterangan yang telah dikemukakan di atas maka dapat dipahami bahwa jihad adalah mencurahkan segala kemampuan yang dimiliki oleh seseorang. Maka kebaikan apapun yang dilakukan oleh seseorang jika dilakukan dengan kekuatan maksimal maka sesungguhnya itu adalah jihad. Ibadah haji adalah ibadah yang membutuhkan kekuatan dan kemampuan baik fisik, financial, maupun mental, maka ibadah haji adalah jihad, itulah sebabnya jihadnya perempuan adalah ibadah haji.

\section{Klasifikasi Jihad dalam Islam}

Jihad dalam al-Qur'an mengandung arti yang sangat luas seluas ajaran Islam yang mengatur seluruh aspek kehidupan umat manusia, dari masalah-masalah yang bersifat individual atau privasi sampai kepada masalah kemasyarakatan dan negara. Menurut Andi Aderus (2017; 9) mengatakan bahwa ulama membagi jihad kepada beberapa bagian sesuai dengan objek jihad yang didefinisikan. Sebagian ulama membagi Jihad kepada dua macam, yaitu: jihad mal (jihad dengan harta) dan jihad nafs (jihad dengan diri atau jiwa raga). Pendapat mereka ini didasarkan dari beberapa firman Allah Swt. dalam al-Qur'an yang berulangkali menyebut dua bentuk jihad tersebut.

Jihad dengan harta yaitu menafkahkan harta benda dijalan Allah swt. untuk kepentingan agama dan kemanusiaan. Menurut ajaran Islam harta yang dimiliki sebagian kecilnya mesti di salurkan pada fakir miskin dan kepentingan-kepentingan sosial. Harta bagi seorang Muslim menjadi sarana untuk mencapai kebahagian dunia dan akhirat sehingga harta yang dimiliki mesti dipertanggungjawabkan di hadapan Tuhan..$^{10}$ Oleh karena itu pemanfaatan harta mesti sesuai dengan nilainilai yang diridhai oleh Allah swt. dan inilah yang dimaksud jihad mal. Yaitu membelanjakan harta benda di jalan Allahswt. Jihad dengan jiwa raga adalah mewakafkan jiwa raga demi tegaknya keadilan yang dapat dirasakan oleh umat manusia sehingga tercipta perasaan aman, bebas tanpa intimidasi. Seorang Muslim dituntut untuk kesatria menegakkan 
kebenaran, memiliki pendirian yang teguh dalam menghadapi segala bentuk intimidasi.

Menurut Ibnu Qayyim jihad terbagi ke dalam tiga bentuk, yaitu jihad mutlaq, jihadhujjah dan jihad 'amm. Pembagian ini dilatarbelakangi oleh kondisi umat Islam pada saat itu, sehingga Ibn Qayyim membagi jihad berdasarkan cara yang dipergunakan dalam menegakkan keadilan dan kebenaran. Jihad mutlaq adalah bersabar menghadapi musuh di medan perang. Islam membenarkan umatlslam untuk mempertahankan diri dan kehormatan, namun Islam melarang umat Islam memulai suatu masalah, bahkan dalam melakukan peperangan,ajaran Islam memberikan aturan-aturan yang sangat ketat sehingga etika dan moralitas senantiasa terjaga meskipun di medan perang. Kontak senjata dalam pandangan Islam adalah jalan terakhir yang tidak bisa dihindari yaitu disaat semua jalan diplomasi sudah tertutup.

Jihad hujjah adalah jihad yang dilakukan oleh para ulama dalam rangka memberikan penjelasan dan dalil-dalil yang logis tentang risalah Islam yang bersifat rahmatan tit 'alamin. Jihad semacam ini juga dikenal dengan da'wah bi al-lisan. Jihad 'amm yaitu jihad yang merangkumi seluruh aspek kehidupan, baik yang bersifat moral maupun material. Jihad ini dapat dilakukan melalui harta, jiwa, tenaga, waktu, dan ilmu pengetahuan yang dimiliki. Jihad dalam konteks ini melibatkan seluruh umat Islam tanpa kecuali. Bahkan Rasulullah saw. menegaskan bahwa pekerjan yang paling disenangi oleh Allah swt. adalah pekerjaan yang dilakukan dengan sungguh-sungguh."

Jihad terhadap hawa nafsu merupakan jihad yang paling tinggi karena jiwa manusia cenderung melakukan pelanggaran. Di samping itu manusia cenderung untuk memuaskan hawa nafsunya, melawan hawa nafsu yang mendorong pada perbuatan keji dan munkar serta mencari kepuasan jauh lebih sulit dari hanya sekedar berperang di medan laga, sebab berperang di medan lagi adalah sejalan dengan jiwa manusia yang cenderung untuk melawan musuhnya sehingga jihad melawan hawa nafsu jauh lebih susah dibanding bentuk- bentuk jihad yang lain.

Berjihad dengan anfus, bisa berupa dengan tenaga dan jiwa. Dalam kondisi damai, jihad dengan anfus ini bisa dilekatkan kepada beberapa predikat, seperti jihad dakwah dengan amar ma'ruf dan nahimunkar, jihad pendidikan dan jihad intelektual (Jihad bial-lisan aw bial-qalam). Abd. Halim Mahmud (2001; 131-132) mengatakan bahwa jihad dewasa ini memiliki bidang yang amat luas, tidak sekadar amar 
ma'ruf dan nahi munkar. Sebab terkadang kemungkaran yang ingin dirubah posisinya sangat kuat dan tidak mempan dengan ajakan, ceramah dan nasihat atau cara-cara persuasif.

Menurut Imam Ragib al-Isfahani dalam M. Quraish Shihab (1996; 499) kata jihad dalam al-Qur'an mempunyai tiga arti, yaitu: (1) berjuang melawan musuh nyata, (2) berjuang melawan (memusuhi) syetan, dan (3) berjuang melawan hawa nafsu. Sebagaimana dijelaskan dalam al-Qur'an Surat al-Haj/22: 78 dan Q.S. al-Baqarah/2: 218.

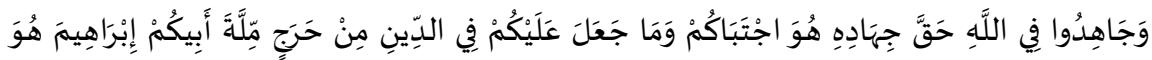

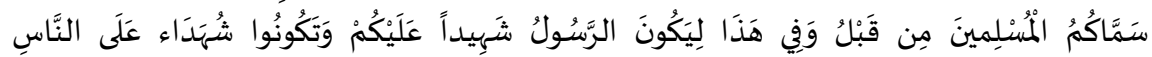

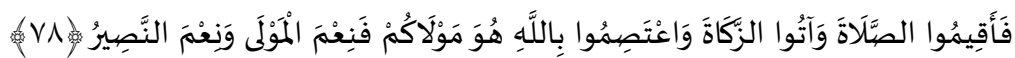

Dan berjihadlah kamu pada jalan Allah dengan jihad yang sebenarbenarnya. Dia telah memilih kamu dan Dia sekali-kali tidak menjadikan untuk kamu dalam agama suatu kesempitan. (Ikutilah) agama orang tuamu Ibrahim. Dia (Allah) telah menamai kamu sekalian orang-orang muslim dari dahulu, dan (begitu pula) dalam (Al Qur'an) ini, supaya Rasul itu menjadi saksi atas dirimu dan supaya kamu semua menjadi saksi atas segenap manusia, maka dirikanlah sembahyang, tunaikanlah zakat dan berpeganglah kamu pada tali Allah. Dia adalah Pelindungmu, maka Dialah sebaik-baik Pelindung dan sebaik-baik Penolong.

Ibn Qayyim al-Jauziyah (1999: 175) mengatakan bahwa jihad terdiri dari empat martabat, yaitu: (1) jihad terhadap nafsu, (2) jihad terhadap syaitan, (3) jihad terhadap orang kafir, dan (4) jihad terhadap orang munafik.

Sedangkan Hilmi Bakar al-Mascaty (2001:36) mengemukakan bahwa jihad itu meliputi jihad amwal (harta), jihad anfus (jiwa), jihad ta'limy (jihad pendidikan), jihad siyasy (politik), dan jihad ma'rifah (pengetahuan).

Berdasar dari keterangan di atas, maka lahirlah teori tentang jihad besar dan jihad kecil. Teori didasarkan pada salah satu riwayat ketika Rasulullah Saw. kembali dari medan pertempuran, dimana beliau menyampaikan kepada para sahabat bahwa "kita kembali dari jihad kecil menuju jihad besar". Jihad besar yang dimkasud adalah jihad melawan hawa nafsu, yaitu kemampuan mengendalikan hawa nafsu agar tidak terdorong melakukan tindakan asusila, menghindari sifat rakus, egois, khianat, kikir, tidak adil, dendam, dengki dan lainlain. Berjihad juga bukan hanya meliputi jihad dengan raga tetapi juga jihad dalam bentuk pengorbanan harta benda. Sebagaimana firman 
Allah Swt. dalam Q.S. al-Anfal/8: 72

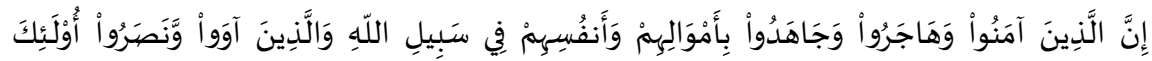

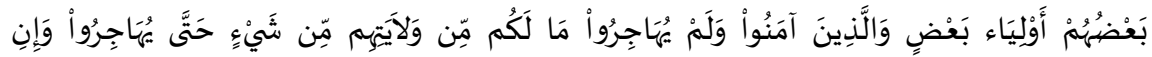

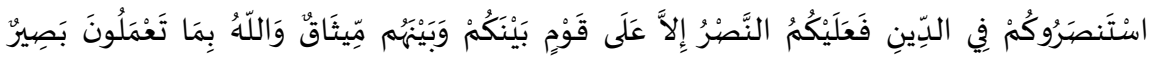

Sesungguhnya orang-orang yang beriman dan berhijrah serta berjihad dengan harta dan jiwanya pada jalan Allah dan orang-orang yang memberikan tempat kediaman dan pertolongan (kepada orang-orang muhajirin), mereka itu satu sama lain lindung-melindungi. Dan (terhadap) orang-orang yang beriman, tetapi belum berhijrah, maka tidak ada kewajiban sedikitpun atasmu melindungi mereka, sebelum mereka berhijrah. (Akan tetapi) jika mereka meminta pertolongan kepadamu dalam (urusan pembelaan) agama, maka kamu wajib memberikan pertolongan kecuali terhadap kaum yang telah ada perjanjian antara kamu dengan mereka. Dan Allah Maha Melihat apa yang kamu kerjakan.

Jihad fi sabilillah atau berjihad di jalan Allah yang sering ditemukan dalam hadis-hadis Rasulullah sebagai amalan yang terbaik tidak dapat dibatasi maknanya, tetapi diperluas bahwa bukan arti perang atau angkat senjata, melainkan juga bermakna berjuang melawan kemiskinan, kebodohan, keterbelakangan, penindasan, pemerkosaan dan sebagainya (Hasbi al-Shissieqy, 1998:67).

Demikian keterangan al-Qur'an dan hadis Rasulullah Saw. tentang jihad yang memiliki arti yang sangat universal, bukan hanya perlawanan terhadap musuh dengan senjata tetapi memberantas kebodohan, kemiskinan termasuk kegiatan jihad fi sabilillah (jihad di ajalan Allah). Setiap pekerjaaan yang dilakukan dengan sungguhsungguh dapat dikategorikan jihad, seorang ilmuan bisa berjihad dengan memanfaatkan ilmunya, karyawan dapat bekerja secara profesional dan penuh tanggung jawab, guru yang dapat mengajar dan mendidik dengan sebaik-baiknya, pemimpin dengan keadilannya, pengusaha dengan kejujurannya dan lain-lain.

Jihad memiliki empat tingkatan: jihad melawan nafsu (diri sendiri), jihad menghadapi setan, jihad melawan orang-orang kafir dan munafik, serta jihad memberantas kezaliman, bid'ah, dan kemungkaran. Tingkatan pertama: Jihad melawan nafsu, Jihad melawan nafsu memiliki empat tingkatan: 1) Jihad melawan nafsu untuk belajar ilmu-ilmu agama. 2) Jihad melawan nafsu untuk 
mengamalkan apa yang telah dipelajari. 3) Jihad melawan nafsu mendakwakan ilmu tersebut dengan penuh hikmah dan mengajarkannya kepada orang yang belum mengetahuinya. 4) Jihad melawan nafsu untuk tetap bersabar dalam mengemban tugas berat berdakwah kepada Allah dan bersabar dari gangguan orang lain. Dan menghadapi semua itu semata-mata karena Allah swt.

Tingkatan kedua: Jihad melawan setan. Jihad melawan setan memiliki dua tingkatan: 1) jihad melawan syubhat dan keraguan yang membahayakan iman yang dihembuskan oleh setan. 2) Jihad melawan syahwat dan keinginan buruk yang dibisikkan oleh setan. Jihad yang pertama dilakukan setelah mantapnya keyakinan, sedangkan jihad yang kedua dilaksanakan setelah adanya kesabaran.

Tingkatan ketiga: Jihad melawan orang kafir dan munafik. Jihad ini memiliki empat tingkatan: hati, lisan, harta, dan tangan (kekuatan). Jihad melawan orang kafir lebih banyak menggunakan tangan, dan jihad melawan orang munafik lebih banyak menggunakan lisan. Tingkatan keempat: Jihad memberantas kezaliman, ketidakadilan, bid'ah, dan kemungkaran. Jihad ini memiliki tiga tingkatan: 1) Jihad dengan tangan (kekuatan), jika seorang mujahid mempunyai kemampuan untuk itu. 2) Jika tidak mampu dengan tangan, maka jihad dilakukan dengan lisan. 3) Jika masih merasa tidak mampu, maka cukup berjihad dengan hati (dengan mengingkari).

Pada umumnya ayat-ayat jihad dalam Al-Qur'an mengandung arti: mengerahkan segala kekuatan untuk menyebarkan dan membela dakwah Islam. Dalam penyebaran dakwah berpatokan kepada bi alhikmah wa al-mauizah al-hasanah dan berdialok dengan cara yang terbaik. Dr. Sigrid Hunke, Orientalis wanita Jerman - yang dikenal jujur dalam setiap tulisan-tulisannya mengenai Islam - mendefinisikan jihad dalam Islam sebagai berikut: dalam Islam bukan perang yang distilahkan dengan perang agama sebagaimana persepsi orang-orang Barat selama ini.

Tetapi Jihad adalah setiap tindakan yang disertai dengan kesungguhan, setiap ketekunan yang bermanfaat, dan setiap ketegaran iman dalam jiwa, sehingga kita mampu bertarung melawan berbagai macam tantangan dalam kehidupan ini, yang terus berkembang setiap waktu dalam jiwa kita, dan dalam lingkungan kita. Maka dari itu Jihad merupakan sumber mata air yang tidak pernah berkurang untuk diminum setiap muslim untuk dijadikan sebagai sumber kekuatan dan energi sehingga tercipta sebuah kesiapan sempurna dalam memikul sebuah tanggung jawab untuk tunduk dihadapan kehendak Allah swt. 
yang berdasarkan kesadaran dan keyakinan. Sesungguhnya jihad itu merupakan bentuk kesiap-siagaan yang selama-lamanya untuk Ummat Islam sebagai bentuk pembelaan diri dari kekuatan-kekuatan yang memusuhi Islam demi tegaknya syariat Islam dalam kehidupan sosial yang islami dalam Negara Islam

\section{Jihad dalam al-Qur'an bukan Terorisme}

Terorisme dalam asumsi Barat adalah kegiatan yang melibatkan unsur kekerasan atau yang menimbulkan efek bahaya bagi kehidupan manusia yang melanggar hukum pidana, yang jelas dimaksudkan untuk: a) mengintimidasi penduduk sipil, b) mempengaruhi kebijakan pemerintah dan, c) mempengaruhi penyelenggaraan negara dengan cara penculikan atau pembunuhan.

Maka hakekat perbuatan Terorisme mengandung perbuatan kekerasan atau ancaman kekerasan yang berkarakter politik. Bentuk perbuatan bisa berupa perampokan, pembajakan maupun penyanderaan. Pelaku dapat merupakan individu, kelompok, atau Negara. Teroris merupakan orang yang menggunakan kekerasan yang tidak disyariatkan untuk menakut nakuti orang yang hidup dalam kedamaian, dan memaksakan mereka untuk menerima yang tidak diinginkannya. Khususnya apabila terorisnya menduduki kursi kekuasaan berusaha untuk menakut-nakuti rakyatnya sendiri. Persepsi ini tentu bertentangan dengan ajaran Islam yang kehadirannya sebagai rahmatan lilalamin.

Istilah jihad sering muncul ketika terjadi aksi-aksi kekerasan sehingga berdampak pada terjadinya kesalahpahaman dalam memahami istilah jihad sebagai perjuangan pisik atau perlawanan dengan bersenjata. Kesalahpahaman ini disuburkan juga oleh terjemahan yang keliru terhadap ayat-ayat al-Quran yang berbicara tentang jihad dengan anfus. Kata anfus sering kali diterjemahkan dengan jiwa.

Sebenarnya banyak arti dari nafs/anfus dalam al-Quran, sekali berarti nyawa dan kali lain berarti hati, di tempat lain berarti jenis dan ada pula yang berarti totalitas manusia, dimana terpadu jiwa dan raganya (Wahyun Mawardi, 2016). Al-Quran mempersonifikasikan wujud seseorang di hadapan Allah dan masyarakat dengan menggunakan kata nafs. Kalau demikan, tidak meleset jika kata itu dalam konteks jihad dipahami dalam arti totalitas manusia, sehingga kata nafs mencakup nyawa, emosi, pengetahuan, tenaga, pikiran, walhasil totalitas manusia, bahkan waktu dan tempat, karena manusia tidak dapat memisahkan diri dari keduanya. Firman Allah misalnya 
dalam QS. al-Baqarah (2): 218

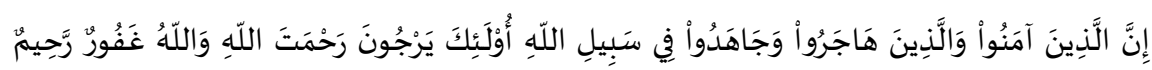

Sesungguhnya orang-orang yang beriman, orang-orang yang berhijrah dan berjihad di jalan Allah, mereka itu mengharapkan rahmat Allah, dan Allah Maha Pengampun lagi Maha Penyayang.

Menurut M. Quraish Shihab (2002) jihad adalah berjuang tiada henti dengan mencurahkan segala yang dimilikinya hingga tercapai apa yang diperjuangkannya, perjuangan dengan harta, atau apapun yang dimiliki, dengan niat melakukan di jalan Allah yang mengantar kepada ridha-Nya. Adapun jihad atau peperangan yang diizinkan al-Quran hanya untuk menghindari terjadinya penganiayaan. Sebagaimana firman Allah dalam Q.S. al- Baqarah (2): 190 sebagai berikut:

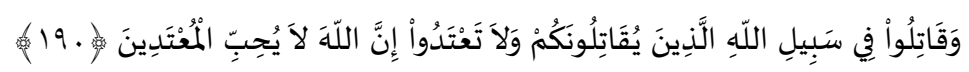

Dan perangilah di jalan Allah orang-orang yang memerangi kamu, (tetapi) janganlah kamu melampaui batas, Karena Sesungguhnya Allah tidak menyukai orang-orang yang melampaui batas.

Kata "melampau batas" dalam ayat di atas dimaknai oleh Nabi saw. dengan membunuh wanita, anak kecil, dan orang tua. Bahkan oleh al- Quran salah satu pengertiannya adalah tidak mendadak melakukan penyerangan. Sebelum terjadi keadaan perang dengan pihak lain itu jika sebelumnya ada perjanjian perdamaian dengan suatu kelompok, perjanjian harus dinyatakan pembatalannya secara tegas terlebih dahulu. Al-Quran menegaskan dalam Q.S. al- Anfal/8: 58 sebagai berikut:

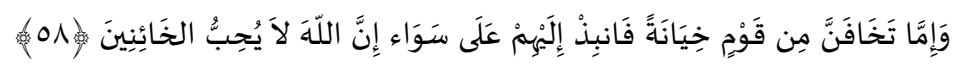

Dan jika kamu khawatir akan (terjadinya) pengkhianatan dari suatu golongan, Maka kembalikanlah perjanjian itu kepada mereka dengan cara yang jujur. Sesungguhnya Allah tidak menyukai orang-orang yang berkhianat.

Peperangan yang dilakukan terhadap orang-orang kafir sesungguhnya bukan karena kekufuran atau keengganan mereka memeluk Islam, tetapi karena penganiayaan yang mereka lakukan terhadap hak asasi manusia untuk memeluk agama yang dipercayainya. Peperangan pada hakikatnya tidak dikehendaki oleh Islam, adanya peperangan dalam Islam adalah upaya untuk melakukan pembelaan. 
Berdasarkan keterangan di atas dapat dipahami bahwa pada dasarnya umat Islam dilarang mencari musuh, memerangi kelompok yang ingin hidup berdampingan dengan umat Islam. Maka suatu persepsi yang keliru jika memerangi orang-orang yang dianggap sebagai musuhnya dengan dalih jihad dan penuh harapan ingin mendapatkan predikat syahid fi sabilillah, sebagaimana yang terlihat sekarang adanya sekelompok umat Islam yang melakukan hal tersebut. Dengan kata lain bahwa yang berkaitan dengan terorisme, dan dipraktekkan oleh sebahagian kalangan Islam tertentu, dan mengundang kontroversi dalam Islam. Mereka melakukan tindakan bunuh diri dengan mengharapkan mati syahid, sementara ajaran Islam tidak membenarkan, bahkan mengharamkan tindakan bunuh diri.

Spektrum jihad dalam ajaran Islam sebetulnya sangat luas, sayangnya dalam kenyataan, tidak jarang orang melakukan pemaknaan jihad semata-mata untuk dijadikan alat pembenar bagi tindakannya yang justru melenceng dari konteks jihad itu sendiri. Distorsi makna jihad kadangkala juga dibesar-besarkan oleh media massa, misalnya koran-koran mem-blow up maraknya posko pendaftaran sukarelawan ke daerah-daerah konflik, pendaftarnya melimpah. Berita-berita mengenai aksi sweeping warga Amerika di beberapa kota, yang boleh jadi dengan gampang orang menudingnya sebagai implementasi dari jihad, sehingga lengkaplah stigmatisasi atau pencitraan buruk mengenai jihad.

Hal yang demikian mencerminkan stereotipe jihad dalam persepsi sebagian masyarakat muslim, jihad selalu dididentikkan dengan tindak kekerasan, sehingga jihad dalam benak mereka menjelma teror yang amat mencekam. Padahal, sesungguhnya tidak demikian. Jihad adalah usaha dengan segala daya upaya untuk mencapai kebaikan, usaha sungguh-sungguh membela agama Islam dengan mengorbankan harta benda, jiwa dan raga.

Agama Islam yang sesungguhnya adalah agama yang damai, mengajarkan kasih sayang dan cinta sesama, hal itu dapat dibuktikan dengan kehadiran Rasulullah Nabi Muhammad saw. sebagai Nabi yang diutus sebagai rahmat bagi seluruh umat manusia, bahkan bukan hanya kepada manusia, tetapi tumbuh-tumbuhan, binatang sekalipun. Allah Swt, berfirman dalam Q.S. al-Anbiya/21: 107 sebagai berikut:

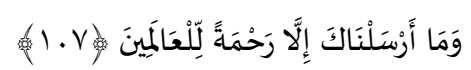

"Dan tidaklah Kami mengutus engkau melainkan sebagai rahmat bagi 
semesta alam" (21:107).

Berdasar dari ayat di atas, maka dapat dipahami bahwa Nabi Muhammad saw. yang telah dikirim sebagai sumber rahmat bagi seluruh umat manusia, sehingga dapat dipastikan bahwa baik beliau saw. ataupun para pengikutinya tidak akan mungkin menjadi sarana kerusakan dan penderitaan bagi siapapun di dunia. Itulah ajaran Islam yang sesungguhnya yaitu mengajarkan kedamaian dan kasih sayang. Islam Adalah Agama yang diturunkan oleh Allah Swt. Sang Maha Pengasih dan Maha Penyayang (Rahman dan Rahim), oleh karena itu Dia memerintahkan umat Islam untuk saling berkasih sayang antara satu dengan yang lain. Bahkan menjadi syarat bagi seseorang yang ingin mendapatkan rahmat dari Allah Swt. Rasulullah saw. bersabda:

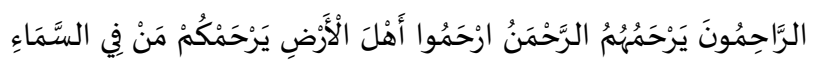

“Orang-orang yang berbuat kasih sayang akan disayang oleh 'ArRahman' (Yang maha Penyayang), maka sayangilah siapa saja yang ada di muka bumi ini niscaya engkau akan disayang oleh (Allah) yang ada di atas langit." (HR. Ahmad dan Abu Dawud).

Sifat Rahman yang dimiliki oleh Allah Swt. juga tercermin dari ajaran-Nya yang tidak memaksakan manusia untuk mengikuti tuntunan-Nya. Sebagaimana tercantum dalam Q. S. al-Baqarah/2: 256 sebagai berikut:

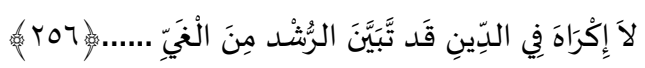

"Tidak ada paksaan untuk (memasuki) agama (Islam); sesungguhnya telah jelas jalan yang benar daripada jalan yang sesat."

Manusia mendapatkan kebebasan dari Allah untuk memilih beragama atau tidak beragama. Manusia pun berhak mengklaim bahwa agama yang dipilihnya adalah agama yang benar. Dengan demikian, sikap saling menghormati kepercayaan dan agama yang berbeda harus diimplementasikan dalam kehidupan umat manusia. Sikap saling menghormati dan saling menghargai akan melahirkan kerukunan dalam kehidupan beragama (Rasyid Rida, 1999).

Kebebasan beragama pada hakikatnya adalah dasar bagi terciptanya kerukunan antar umat beragama. Tanpa kebebasan beragama tidak mungkin ada kerukunan antar umat beragama. Kebebasan beragama adalah hak setiap manusia. Hak untuk menyembah Tuhan diberikan oleh Tuhan, dan tidak ada seorang pun yang boleh mencabutnya. 
Toleransi antar umat beragama adalah cara agar kebebasan beragama dapat terlindungi dengan baik. Kebebasan dan toleransi tidak dapat diabaikan. Namun yang sering kali terjadi adalah penekanan dari salah satunya, contohnya penekanan kebebasan yang mengabaikan toleransi dan usaha untuk merukunkan dengan memaksakan toleransi dengan membelenggu kebebasan. Untuk dapat mempersandingkan keduanya, pemahaman yang benar mengenai kebebasan beragama dan toleransi antar umat beragama merupakan sesuatu yang penting dalam kehidupan bermasyarakat, berbangsa dan bernegara.

Manusia adalah makhluk individu sekaligus makhluk sosial. Sebagai makhluk individu ia memiliki karakter yang unik, yang berbeda satu sama lain dengan fikiran dan kehendaknya yang bebas. Sedangkan keberadaannya sebagai makhluk sosial ia membutuhkan manusia lain, membutuhkan sebuah kelompok dalam bentuknya yang minimal, yang mengakui keberadaannya dan dimana dia dapat bergantung. Kebutuhan untuk berkelompok ini merupakan naluri alamiah sehingga kemudian muncullah ikatan-ikatan yang dalam islam dikenal dengan istilah ukhuwah.

Tumbuhnya sikap ukhuwah dalam diri setiap individu maka akan melahirkan kedamaian hidup dalam kehidupan bermasyarakat, berbangsa dan bernegara. Oleh karena itu, pemahaman terhadap ukhuwah sangat penting dalam rangka meminimalisir terjadinya gesekan-gesekan karena perbedaan suku, agama, dan menghindari terjadinya disintegrasi yang dilatar belakangi oleh berbagai perbedaan kepentingan.

\section{Kesimpulan}

Berdasarkan hasil penelitian dan pembahasan yang telah dikemukakan sebelumnya, maka ditarik kesimpulan sebagai berikut:

1. Term jihad dalam al-Qur'an mengandung arti bersungguh-sungguh dalam melakukan suatu pekerjaan, maka seorang ilmuan bisa berjihad dengan memanfaatkan ilmunya, karyawan berjihad dengan bekerja secara profesional dan penuh tanggung jawab, guru berjihad dengan mengajar dan mendidik dengan sebaik-baiknya, pemimpin dengan keadilannya, pengusaha dengan kejujurannya. 
2. Bentuk-bentuk jihad dalam al-Qur'an antara lain: jihad dengan jiwa, harta, dan lisan. Maka Jihad merupakan kerja profesional dalam segala aspek kehidupan yang disertai dengan pengorbanan jiwa (totalitas manusia) dan harta benda, dalam upaya dengan sungguh-sungguh untuk mendekatkan diri kepada Allah Swt. dan berupaya menyingkirkan segala bentuk yang menghalanginya.

3. Terorisme tidak dikenal dalam Islam karena Islam tidak mengajarkan kekerasan, oleh karena itu terorisme tidak dapat dikaitkan dengan term jihad yang diajarkan dalam Islam, misi utama Islam adalah rahmatan lil'alamin. 


\section{Daftar Pustaka}

Ahmad Ibn Taymiyyah, Taqiyuddin. T.th. Majmu' al-Fatawa. Beirut: Daar al-Fikr.

al-Farmāwī, 'Abd al-Hayy. 1977. Al-Bidāyah fì al-Tafsīr al-Mauḍūî̀. Cairo: al-Ḥaḍārah al-'Arabiyyah.

Al-Jauziyah, Ibn Qayyim. 1997. Zaad al-Miad Fi hadyi Khairil 'Ibad. Beirut: Muassasah Arrisalah.

Banua, Andi Aderus. 2017. Jihad Menuju Islam Rahmatan lil Alamin dalam buku Jihad dalam Islam ; Kedamaian atau Kekerasan. Yogyakarta: Ladang Kata.

Chirzin, Muhammad. 1997. Jihad dalam al-Qur'an; Telaah Normatif, Historis dan Perspektif. Yogyakarta: Mitra Pustaka.

Departemen Agama RI. 2016. Al-Qur'an dan Terjemahnya. Jakarta: CV. Dārus Sunnah.

Harisah, Afifuddin. 2017. Jihad Kaum Sarungan (Perspektif "Fikih" Pesantren di Sulawesi Selatan) dalam buku Jihad dalam Islam; Kedamaian atau Kekerasan. Yogyakarta: Ladang Kata.

Mahmud, Abd Halim. 2001. Manhaj al-Istäh al-Islämiß al-Mujtama', Kairo: Matäbi' al- Hay'ah al-Misriyyah al-'Ämmah Ii al-Kitäb.

Mansur, H. A. Sutan. 1987. Jihad. Jakarta: Panji Masyarakat.

Mardan. 2009. Wawasan Al-Qur'an tentang Malapetaka. Jakarta: Pustaka Arif.

Riḍā, Muḥammad Rasyīd. 1999. Tafsīr al-Manār, juz 1 (Cet. 1; Beirut: Dār al-Kutub al-'Ilmiyyah.

Sabiq, Sayyid. 1982. Fiqh Assunnah. Beirut: Daar al-Fikr.

Shihab, M. Quraish. Membumikan al-Qur'an; Fungsi dan Peran Wahyu dalam Kehidupan Masyarakat. Cet. 10; Bandung: Mizan, 1995. 
Amri Rahman - Memahami Jihad dalam Perspektif Islam (Upaya Menangkal Tuduhan Terorisme dalam Islam)

Tafsir Al-Misbah; Pesan, Kesan, dan Keserasian al-Qur'ân. Vol. 1, 2,

3, 5, dan 13. Cet. 1; Jakarta: Lentera Hati, 2002.

Wawasan Al-Qur'an. Cet. 8; Bandung: Mizan, 1998.

Thayyeb, Prof. Dr. Ahmad. 2016. Pengertian Jihad dalam Islam. ww.waagazhar.org/id/Makalat1. 